\title{
Aparecidos: Fear, Fact, and Fiction as Means to Truth
}

\author{
Ana Torres ${ }^{1}$
}

This article is an analysis of the Argentine/Spanish horror film Aparecidos that is based on historical atrocities. I analyze the reality of the Argentine Dirty War of the 1980s as it is depicted through allusions, illusions, and delusions as a brother and sister who have been in exile in Spain return to Argentina to disconnect their father from a life-support apparatus. They become aware of their father's involvement with the torture and murder of the desaparecidos. The study should shed new light on the children who grow up without knowing about their true families as well as their fates. . [Article copies available for a fee from The Transformative Studies Institute. E-mail address: journal@transformativestudies.org Website: http://www.transformativestudies.org (C2018 by The Transformative Studies Institute. All rights reserved.]

KEYWORDS: Argentina, Dirty War, Horror Films, Desaparecidos, Black Market Babies.

The Argentine Dirty War that occurred from 1975 to 1986, a brutal and horrific decade, has left survivors searching for closure and healing. According to Charles St. Georges, "The relatively unknown 2007 Spanish-Argentine co-production Aparecidos. . .presents an interesting dilemma about the ethics of the cinematic representation of real-life horrors. . based on the Dirty War. . . and the estimated thirty thousand desaparecidos who were abducted, tortured, and made to disappear" (85). St. Georges questions the use of the horror genre to depict historical events for commercial purposes, but acknowledges that perhaps it is the best means to reach a younger audience uninterested in and ignorant of its country's recent history. Nevertheless, José Mariano Leyva, minimizes this dilemma when he states, ". . . una película sobre historia no ... tiene el deber ético de buscar la verdad, pero muchas veces nos

\footnotetext{
${ }^{1}$ Ana Torres, Ph.D., is an associate professor of Spanish at Armstrong State University in Savannah, Georgia. She holds degrees from Inca Garcilaso de la Vega in Peru, as well as her M.A. and Ph.D. in Spanish from Florida State University. Her research interests include Spanish American film and literature.
} 